\title{
The Biblical Subtext in The Exchange by Paul Claudel
}

\author{
Ann Bugliani \\ Loyola University, Chicago
}

I $\mathbf{n}$ a letter to Jean-Louis Barrault, Paul Claudel reveals that the fundamental idea of The Exchange is a religious one. The play was written in 1893 when he was still in the midst of the fervor of his conversion three years earlier. It was also the product of his first encounter with the United States, his experiences with the practical life as he began his diplomatic career, and his attempt to grapple with forces within himself which demanded attention at that time. More than fifty years later, the mature Claudel revised the play on the occasion of its performance by the Madeleine Renaud/Jean-Louis Barrault Company in 1951. It is this second, mature version which I have chosen to analyze in the light of its Biblical inspiration.

It may be said that the four characters of the play represent the seemingly contradictory calls or vocations which the young Claudel faced in his youth. Among the American characters, Louis Laine depicts freedom, independence, and adventure; Thomas Pollock Nageoire, business and the practical life; Lechy Elbernon, free love, art, and fantasy. On the other hand, Martha, the only French character, portrays the conservative values of church, family, conscience and commitment. $(T, 1299)$

As the play begins, we immediately perceive Martha engaged in an activity which is somehow very much in character for her Biblical namesake, Martha of Bethany, sister to Mary and Lazarus and friend of Jesus. We will have occasion to comment further concerning the Biblical inspiration for this character. Now, let us simply note that she is mending, repairing her husband's clothes. He appears on stage naked, suggesting, within the Biblical context, a certain vulnerability. Scripture tells usw that we are to be clothed, clothed with righteousness, faith, and truth; we are to wear these as an armor which will protect us against the spiritual forces of evil (Ephesians 6:11-17). Our hero Louis is instead naked; his wife Martha is mending his clothes-attempting to piece together a covering for him. 


\section{Ann Bugliani}

As their conversation begins we discover that Louis, who has not spent the night with Martha, has just come from a swim the object of which was the retrieval of a gold coin thrown into the water by Thomas Pollock Nageoire. The parable of the lost coin immediately comes into mind. (Luke 15:8-1o) This parable is interesting because in it the lost coin is clearly like the lost sheep which the good shepherd diligently seeks. Louis, curiously enough, swallows the coin, becoming himself that thing of value which has been lost and is now assiduously sought.

It is highly significant that the very first parable alluded to in the play is one in which a coin, a silver one in the Scriptures and a gold one in our play, takes on, or represents, value which is at once both spiritual and material. In a sense, Claudel's play, as we shall see, is a meditation on the principle of the exchange and on value itself, an appropriate meditation for the young Claudel who had to make important choices in life. And although I will demonstrate that this meditation has profound scriptural roots, it should be noted that the play also contains a critique of Biblebased American Protestantism. This is apparent at the outset when we discover that Louis, a dyed-in-the-wool American with some Native American blood, was wont to read the Bible in his father's coal bin as a child, but in spite this, he also used to steal from his father. Somehow his Biblical instruction had little efficacy.

As Louis evokes his voyage to the new world with Martha, his French wife, he recalls that Martha had her place in the forward part of the ship where she could serve as guide, whereas he was astern with his face looking back like Lot's wife who was turned into a pillar of salt (Genesis 19:26). Then we are reminded of the gold coin that he swallowed, that treasure now hidden within him, when Martha says: "I sing to that star which had hidden itself in the mud. Although it was well hidden, I've found it again." When we hear Louis respond: "I don't like being found," we understand that he is indeed a lost sheep, as suggested above, but one that does not want to be found. We see, too, that it is Martha who is cast in the role of the shepherd who forsakes all to search for the hidden, or lost sheep. She leaves everything behind in her native France; but, as we have seen, she does not really follow Louis to America, it is as though in some mysterious way she somehow led him there. As the conversation continues, all of this is made even more explicit when Louis asks: "Is it through you that I will be born again?" (Ex 12) It is in fact Martha's job to bring forth in him that which is immortal, the star or the gold hidden within him. 
Thomas Pollock Nageoire's entrance is almost immediately followed by an incredibly graphic description of his value system. "Gold is everything," (Ex 12) he proclaims and then goes on to describe his home in New York. Here we again encounter that strange melange of the material and the spiritual. Just as churches have holy relics at their foundation, his house has as its foundation his treasure-gold, silver, stocks, bonds, and certificates of deposit. It is with religious solemnity that he describes this and tells us that upon this foundation his business offices and his bank have been built. But it is he that is on top of it all and in the middle of everything. He reigns over his empire. He even ascribes to himself god-like attributes when he tells us that he is everything, knows everything, and has done everything. He buys and sells everything. In Thomas, Claudel paints the picture of the supremely self-confident American capitalist, one for whom moneymaking is a more complex process, however, than we would suspect. It is not simply about greed, as we shall see.

When Thomas meets Martha, the conversation centers around her household duties and her marriage and then Thomas makes it a point to tell Martha what he thinks of her husband: "He's good for nothing! Not worth a cent!" And why? Because "he can't handle money, he doesn't pay attention to anything. He is like a man with no pockets!" (Ex 14)

When Thomas is left alone with Louis he brusquely pulls a wad of dollars out of his pocket and then engages in penetrating reflections on money. He holds up the wad with religious reverence, suggesting the elevation during the Mass when the host is consecrated, and then he offers it to Louis explaining its value by saying that everything that can be possessed has a price, and is worth so much in dollars. "If you have this," he tells Louis, "you can exchange it for any thing.... One can have everything if one has the price! Everything has its value in money." (Ex 17) Then begins the seduction of Louis and Thomas' attempt to get what he wants, which is of course Martha. At this point, Thomas seems like a gross materialist, yet we will see that nothing could be further from the truth. Our judgment is nuanced when we hear him admit heroically that has lost everything two or three times. But most interesting is his remark that money is something you exchange for something better. We see then that money is definitely not at the summit of his hierarchy of values.

Another scriptural reference is to be found in Louis' anecdote involving his encounter with an old man who was searching in a marsh for coins. He asked Louis for something to eat in exchange for what he called "God's pardon." Again we think of the parable alluded to at the 


\section{Ann Bugliani}

beginning of the play and the effort required to search for something of value, in this case it is a once more a coin. But the anecdote is important for another reason as well, for it points to a sharp contrast between Louis and Thomas. Louis would not give the man anything thinking that he had no need of "God's Pardon." This response on Louis' part serves to convince Thomas of Louis' lack of worth. Louis has no worth because he does not appreciate what is of worth. He does not value his wife having already betrayed her and he does not value "God's pardon" when it is offered. He is also a man who has no pockets and as a result he and his wife are at the mercy of others. None of this bodes well for him. Because he does not know what things are worth he will not risk something of lesser valuelike food-for something of greater value-like God's pardon or grace. He reminds us of Esau in the Scriptures who preferred a mess of porridge to his birthright. Thomas, on the other hand, knows what things are worth. Unlike Louis, he values money for what it can purchase, he values Martha and does what he can to get her, and as a self-styled religious man he values "God's pardon" for he says: "You never can tell when something like that can do you some good." (Ex 2O) Thomas would have given all he had for God's pardon or grace

In Act Two we hear Louis call his wife Bittersweet and say to her: "You are simple and good, steadfast, straightforward, no one can move you with words: as you were, so you are; you say what you have to say. You are a lighted lamp surrounded by a circle of light." Then he adds: "Sometimes you make me afraid and I would like to hide from you." ( $E x$ 22) She is both bitter and sweet to him and one suspects that it is her virtue, her sweetness, that galls him, just as it is her light that frightens him. In Scripture salvation itself is likened to a lighted lamp (Is. 62:1) and we remember that after the fall Adam hid from the presence of the Lord because he felt guilty and was frightened. (Genesis 3:7-10) Louis goes on to declare that she seems so good, yet he is sure that there must be some vice in her; otherwise, how could she love him? At this she cries out: "Laine-Don't talk that way about yourself! Don't humiliate me!" (Ex 22) and we understand that for Martha they are indeed one flesh and what diminishes him, diminishes her, too. She also believes that their bond is indissoluble for "what God has joined together, man must not separate." (Matthew 19:6) But Louis now tells her that he should never have married her. He cannot fulfill his responsibilities towards her.

When Lechy enters, she quickly reveals that Louis slept with her the night before. And so we see that Louis' betrayal preceded Thomas' 


\section{The Biblical Subtext in The Exchange}

offer of money. Louis has also revealed to Lechy details of his intimacy with his wife. She knows of his nicknames for her-Bittersweet, Peaceful dwelling, and Martha Mary-all of which have scriptural resonance. Bittersweet reminds us of the words in the small scroll that John was instructed to swallow in Revelations 10:9 which would be sweet in his mouth but bitter in his stomach. They would come forth as prophetic words foretelling the final things. Martha, too, will truthfully tell Louis of his past and of the future, a frightening future which, with her, he could avoid. She is a peaceful dwelling. She is Martha Mary, uniting in herself the attributes of Jesus' friends who were the sisters of Lazarus. Martha was the busy, industrious one; Mary was the contemplative who sat at Jesus' feet. Our heroine is both. So it is not surprising to hear her say concerning Lechy: "Look at her and look at me-and rejoice in the exchange you have made!" (Ex 28)

In Act Three, Lechy reminds Martha of the money Thomas offered Louis when she says: “There's money on the altar, offered in the sight of heaven-with a brick on it. It's sacred money.... A sort of sacrament.... More of a sacrament than has ever been between Louis and you." (Ex 34) And one asks: how can mammon be a sacrament? Yet, as we saw from the beginning, Scripture does indeed use money to teach spiritual lessons. Money is a measure of value. We are exhorted to use it wisely: "If you have not been faithful in matters of worldly riches who will entrust to you the true riches?" (Luke 16:11) We are taught in the parables that money must be put to work and not hoarded or squandered. It is clearly not something sacred, but the exchange it is used for is sacred and must be honored. And when we give something to get something else we clearly indicate what our values are. Jesus was sold for thirty silver coins. On the other hand, the kingdom of God is likened to a merchant looking for beautiful pearls. Having found one pearl of exceptional value he went out and sold all he possessed and bought it. (Matthew 13: 45-46)

When Lechy attempts to explain Louis' betrayal, she speaks of need and value. Why has he exchanged Martha, who has great value, for Lechy who has little? Lechy suggests it is because Martha does not need him, although he needs her and he hates her for this. She also calls Martha an angel implying that she is too good for him and he is afraid of her because of this. All of which points to the fact that he does not have sufficient value and she has too much. So although he loves Martha, as Lechy admits, he willingly exchanges her for Lechy who says she needs him. 


\section{Ann Bugliani}

When Louis appears again, he and Martha also speak of the money that Thomas offered him which is still on the table. Martha warns him against leaving the money there doing nothing and we remember the Biblical exhortation to the foolish slave that had buried the money his master had entrusted him with instead of using it: "You should have invested my money with the bankers and on my return I would have gotten my capital with interest." (Matthew 25:27) The consequences of not using what he had been given are dire: the useless servant is to be thrown into the outside darkness. (Matthew 25:30) As if knowing this, Martha says: "It's terrible to have money doing nothing" ( $E x$ 35)

The conversation continues on the swing which is called "that balance of souls." This, too, echoes Scripture. It calls to mind the handwriting on the wall during the feast Nebuchadnezzar's son Belshazzar made in which he and his guests used the sacred vessels from the temple in Jerusalem to drink wine and praise the gods of gold and silver among others. Daniel, the prophet, was called on to interpret the writing which contained three messages all of which seem to be pertinent within the context of our play. Belshazzar is told that he has been weighed in the balances and found wanting, that his days are numbered, and that what is his will be given to others. (Daniel 5: 25-28) All of this would seem to apply to Louis. He, too, has been given a sacred vessel, Martha, whom he has misused; he has worshipped the gods of gold and silver; and when weighed in the balances he has been found wanting; as a result, his days have been numbered and what he has, his wife and child, will be given to another.

In Thomas' last conversation with Martha he tells her that the year has been very bad. He's bluffed his way through but he doesn't know how it will end. He is heavyhearted and would like to stay for a moment with Martha, whom he, too, calls Bittersweet. Then in a remarkable passage he asks her what the substance is that she carries within her that forces those who are with her to notice the disorder within them and to realize that there is an order which they lack. I find the passage remarkable because that lethal substance, or "poison," is, in my view, a paradigmatic example of the pharmakon, the lethal remedy which Derrida so brilliantly analyzed in his essay "Plato's Pharmacy." Martha, like the pharmakon, is a lethal remedy because she is truth and light. There is an exorcism, a dying, or a renunciation which is the price that must be paid for what she offers. The effect of her "poison" is to make Thomas confess that he gave her husband money so that he would leave her. 
Martha reproaches him for separating husband and wife. Then when she asks: "Don't you have enough without taking what little we had as well?" (Ex 4o) we hear echoes of the prophet Nathan who reproached King David for taking Bathsheba from her husband. To do this he likened Uriah, Bathsheba's husband, to a poor man having only one ewe lamb, and David to a rich man with many flocks and herds. Despite his riches, David took Uriah's only treasure, Bathsheba, and then had him killed. (II Samuel 12:1-10)

Thomas continues to plead his case remarking that he is a serious man who knows the worth of things. Martha likens him to a buyer in an estate sale who discovers that he has gotten much more than he bargained for; he has, in fact, purchased a great treasure. With this we think of the pearl of great price or the treasure hidden in the field for which merchants give all that they have. (Matthew 13:44-46) Martha is that pearl and Thomas has recognized her value when her husband did not and he is willing to give what it takes to get her.

She, too, recognizes his value. When he sees something he wants, he does all he can to get it and she appreciates that. Furthermore, he knows the value of things. He is not a dreamer, but a realist. Nothing lies useless in his hands. He is also bold and persevering, which she likes. And there is more. He is calm and prudent, careful, keeping exact accounts; he is patient, cunning, and astute. He is a believer who doesn't trust himself alone. He masters his own desires and bends his reason to reality. According to Martha, for these reasons he is rich. We should note that all of these qualities are lauded in Scripture and characterize the wise man who contrasts with the fool. Louis, instead, would have to be considered a fool; he has none of Thomas' virtues. All the attributes which Martha discerns in Thomas do not, however, convince him that he is rich for he has not succeeded in purchasing the pearl of great price. The money he offered Louis is still on the table and soon all he possesses will go up in smoke. The exchange itself, buying and selling, has left him with little. So we hear him cry: "I am poor." (Ex 42) But we know that this poverty of spirit, this acknowledgment of need, is precisely what is likely to draw to him what he desires.

When his house goes up in flames, Lechy enters to admit her responsibility. She herself is burning and she predicts that Thomas will burn in hell suffering the punishment of the rich. Fire we know is the final test of value. "Of whatever quality each one's work may be, the fire will test it. In case one's construction survives, he will receive his pay. In case 


\section{Ann Bugliani}

one's work is burned down, he will be the loser; though he himself will be saved, yet only as in passing through fire." (I Cor. 3:13-15) God Himself is a consuming fire. (Heb. 12:29) We know, too, that this process is akin to the purification of gold which must be fired to remove its impurities. Faith, we are told, must be tested by fire, like gold (I Pet. 1:7), and we recall the gold coin that Louis swallowed in the beginning of the play. Louis is tested and found wanting; Thomas, on the other hand, survives the ordeal.

Then the long shadow of a horse appears and Lechy tells Thomas to go and stop him because his rider can no longer control him. Thomas returns with Louis' dead body which he places on Martha's lap. In her last words to him Martha likens her heart to a fruit which she had given him to eat, reminding us both of Eve who offered the fruit to Adam and thereby induced him to sin and of Christ who offered us his body to eat and thereby undid the effects of sin. So here again we see that Martha is like the pharmakon. She is both the occasion of sin and the hope of redemption. Lechy, too, shares in this ambiguous nature, and although she, like Louis, is clearly "on the other side of sin," (Ex 37) she, too, was drawn to Martha's light. Now she speaks of herself as one who was sequestered and waited for a deliverance which never came. So she freed herself and wandered the wild places, the arid salt desert, carrying a full vase which broke and the water of her tears was spilled within her like a spring which produced only mud. This somehow reminds us of the unclean spirit who, when he goes out of a person, roams through dry places looking for rest and does not find it. (Matt. 12:44)

As the play draws to a close Thomas cries out to Bittersweet and asks for her hand. At the final curtain Martha, who is light and truth, does indeed extend a hand to Thomas. Now that he has given what he could and been stripped of all the rest, Thomas, the American capitalist who, unlike Louis, does indeed know the value of things, has been touched by grace and has the promise of redemption.

In his own commentary concerning this play, Claudel says that Martha is an incarnation of that mysterious creature in Proverbs 8 who is often called Sophia or Wisdom and who was with God before the creation. He tells us that all of his female characters are a reflection of her. ( $T$ 1303) Thomas, on other hand, is like the unjust steward in scripture who is held up as an example and commended by his master for acting shrewdly and being more astute than the children of the light. (Luke 16:8) (T 130o) Claudel also remarks that real men are completely engaged in life. They 
are not like artists who only have a superficial contact with reality. On the contrary, their whole being-brain, muscles, stomach, and guts-grapples with life. They are in it for real, committed to the hilt. Then he asks provocatively: And isn't every real man a businessman? Perhaps Thomas is, after all, like one of those "publicans" who will precede us into the kingdom of heaven. ( $T$ 1301)

\section{Notes}

1 Paul Claudel, Théâtre, I, Bibliothèque de la Pléiade (Paris: Gallimard, 1965), 1303. Henceforth cited as T.

2 Paul Claudel, The Exchange (Second Version), trans. Louise R. Witherell and H. Lawrence Zillmer (Claudel Studies II.2 [1975]), 11. Henceforth cited as Ex.

3 Jacques Derrida, Dissemination, trans. Barbara Johnson (Chicago: University of Chicago Press, 1981) 120. 